\title{
MANAGEMENT IN MAN'S ENVIRONMENT: HOW UNIVERSAL AND YET UNDER-OBSERVED
}

\author{
Bayo Princewill Lekara $(\mathrm{PhD})^{1}$ and Ebikebena E. Red-Well ${ }^{2}$ \\ Department of Management, Faculty of Management Sciences, Rivers State University, Port \\ Harcourt, Nigeria \\ ${ }^{1}$ Email: bayo.princewill@ust.edu.ng \\ 2Email: redwellemotongha@yahoo.com
}

Cite this article:

Bayo P.L., Ebikebena E.R. (2021), Management in Man's Environment: How Universal and yet Under-Observed. British Journal of Management and Marketing Studies 4(3), 21-29. DOI: 10.52589/BJMMS-

GAZYENGH.

\section{Manuscript History}

Received: 17 Feb 2021

Accepted: 16 March 2021

Published: 26 July 2021

Copyright $\left({ }^{\circ} 2020\right.$ The Author(s).

This is an Open Access article distributed under the terms of Creative Commons AttributionNonCommercial-NoDerivatives 4.0 International (CC BY-NC-ND 4.0), which permits anyone to share, use, reproduce and redistribute in any medium, provided the original author and source are credited.
ABSTRACT: Every university course is developed, taught and learned in the expectation that it will ultimately prove useful to the learner economically or in promoting personal understanding of, and adaptation to the natural and social environments of living and work relations. Management is no exception to this rule. However, because of the general ration that the course management is simple but scarily be sufficiently understood, let alone be made sufficiently relevant today -to-day life and work, the need exists for course lecturers in particular to be adequately equipped to negate these notions and to rather render the course understandable, enjoyable and useful. This paper provides some readily applicable working understandings of and applicative hints on the main branches of management. As an enrichment effort, the meaningful application of some selected information science, or information system - related tertiary level branches of management are also treated to pave the way for the more specially focused paper presentation.

KEYWORDS: Man, Management, Environment, Universal, Under-Observed 


\section{INTRODUCTION}

Every course under the sun is a product of man's attempt at systematically organizing his observations and personal experiences within his day-to-day life-and-work space (i.e. environment of living and work relations) into a meaningful and useful body of understanding information. Hence, management is itself a product of man's conscious interactions with his environment along with his attempt to codify (arrange according to plan or system) his fellow humans, his consistent significant observations and experiences therein. It should be seen as note-worthy that while most members of the organization would preferably have used knowledge, (we have rather deliberately used "information"). For our purposes in this paper, we would seriously plead with the audience to adopt, understanding information", as the core meaning and essence of all "learning" (Blythe et al 1998). This is because knowledge has to mean and indeed to be, man's awareness of the truth which no mortal has ever gained nor can really ever gain. At every point in history, contemporary or current time, men have only constructed and can only construct an understanding largely through personal interpretation of his research or interactive experience within his environment of living and work, which he shares through information communicative transactions (Green, 2001). That is why, some professors at Harvard Graduate School of education, namely Blythe, Perkins and other colleagues now believe that all teaching (i.e. all instructional efforts should only be geared toward developing fluent and publicly communicable and utilizable understanding of the subject matter concerned.

Now, as experience in every discipline or field has consistently shown, the progressive development and communication of experience of any environmental phenomenon invariably tends to culminate in some sort of conceptually or symbolically sophisticated theory. Here at the theoretic phase of courses development, lies the difference between course utility and course worthlessness. Course workers (i.e. course researchers and course educators alike), consciously or uninvitingly make their course useful or worthless to man and society according as they apply (i.e. reconnect) theory to its familiar environmental content of origin or neglect this reconnection (Barnett, Ziegler, Byleen \& Stocker, 2000). It is this reconnection of developed subject theory to its environmental origin which defines understanding and promotes subject utilization for human/societal advancement in every sector (i.e. Government, education, health, welfare, economy/business, industry/commerce, transport, agriculture, etc).

Against this background, the grand purpose of this paper is to attempt to x-ray each of the several branches of management and then to initiate a discourse which seeks to facilitate for lecturers the apt relation of every management lesson to the common environment of the learner and the lecturer, and thereby to optimize learners understanding of management lesson in context.

Management practitioners and employers of labour including educators in higher institutions have no doubts made some effort at relating management practices to real life. Experience shows that through this honest effort at relating management practices to the environmental setting of their original source, poses a challenge which varies in intensity across activities and actions. Simply put, this means that many managers or practitioners assumed certain management practices to be easier and thus, commend such to the environmental activities of our daily practices, living and work. 
Some management activities (e.g. Quantitative Analysis or Technique) get more readily linked to everyday real-life activities such as trading than do others such as computing inventory management in elementary analysis (Osahogulu, 2006).

In the case of educators, Osahogulu (2006) states that management lesson application to the environment poses a great challenge; in some cases, it happens simply because a facilitative application principle is yet to be provided for graduate assistance and others.

Hence, the problem of management practices is yet unsolved on how practical it is to relate every management activity to the environment of real life and its workplaces. The ensuing philosophical questions are asked by managers after facing problems based on held hypothesis:

1. Is it me as a manager that is responsible?

2. Is it a training, knowledge or tools issue?

- Setting up a training and development plan and ensuring that they get the training that they have the tools they need to perform their work.

- Make sure they have the tools they need to do the job efficiently.

- In some cases, knowledge acquired may be an issue to consider.

3. Do they understand what is expected of them when doing their work?

4. Have I used the required means to communicate what is required clearly enough?

5. Is the job description clear?

6. Did they get enough guidance on the task (review tasks and expectations and check this by asking the employee to explain their understanding of the tasks).

7. Is this a new issue where they previously have a good performance?

- Look at past performance, review if the work, or the workload, has changed; talk with the employee and get their thoughts.

8. Is it something different about or separate to the works? Are they distracted by some external personnel issue?

- Avoid asking direct personal questions but try to make sure that the employee knows of your concern.

- Don't try to solve personal issues or problems.

- Allow time for them to handle their situation, show concern and plan date to meet again and see if they have resolved it.

- Limit your opinions to work matters only

9. Is there a workplace environment issue?

10. Is the employee not suited for the job? 
- This may have resulted from poor recruitment, or as a result of the workplace change. Remember that very few employees come to work not wanting to be successful in their job. It can be soul-destroying and stressful to an employee when they feel that they cannot deliver in their role. Issues like this need to be treated with care after you have gone through all of the steps for managing performance issues then you may be able to work with the employee to see if there are other solutions such as a different job either inside or outside the organization.

11. Are the employers or employees performing poorly in many things and does not show any motivation?

\section{The branches of Management and their Sub-problems}

Towards the end of the $20^{\text {th }}$ century, management came to consist of six separate branches, namely:

1. Financial management

2. Human resource management

3. Information technology management (responsible for management information systems).

4. Marketing management

5. Operations management and production management.

6. Strategic management and policy making.

1. Financial Management: Financial Management is of the decision-making, planning and control subsystems of an enterprise. It incorporates the:

- Treasury function, which includes the management of working capital and the implications arising from exchange rate mechanisms due to international competition.

- Evaluation, selection, management and control of new capital investment opportunities.

- Raising and management of the long-term financing markets for a company.

- Need to understand the strategic planning process necessary to manage the long and short-term financial activities of a firm. Financial Manager encounter problems such as

1. Lack of proper planning

2. Unfavourable input-output ratio

3. Cost of capital

4. Problem of pricing \& raising cash

5. Problems of surpluses

6. Problem of raising loans \& repaying debt 
7. Problem of budgeting

8. Problem of delegation of authority

9. Internal audit

10. Role and responsibilities of financial advisor

11. Problem of inventory holdings

12. Problems of calling reports

13. Problem of performance

14. Disinvestment policy of the organization or government.

Therefore, understanding financial management problems requires analytical dexterity and strategic vision. All organizations, regardless of the size, put procedures into place that enable personnel to increase revenues while slashing costs. Even non-profit institutions such as government agencies and charities cope with the challenges that come with running efficient operations.

2. Human Resource Management: One of the measures of success of our civil service is our responsiveness to the changing needs and it is a long- established task within the management framework. Through this task the managers meet its obligation to be a good employer, secure staff commitment: and develop and manage staff to give up their best to help the manager serve organizations. The need to respond to changing the organization expectations means that the task of managing our staff better is more important than ever.

The underlying forces behind the evaluation and development of human resource management have been (and are still) mainly environmental, and the quest for knowledge of better ways of acquiring and utilizing labour.

The "management of man" is a very important and challenging job because of the dynamic nature of the people. No two people are similar in mental abilities, tactical sentiments, and behaviours. They differ widely also as a group and are subject to many varied influences.

To meet all human resource management challenges due to the fluctuating economy as well as local and global advancements, there are many changes occurring rapidly that affect HR in a wide range of issues. These include:

1. Change management

2. Leadership development

3. HR effectiveness measurement

4. Organizational effectiveness

5. Compensation

6. Staffing: Recruitment and availability of skills local labour. (Local content). 


\section{Succession planning}

8. Learning and development

9. Staffing Retention

10. Benefits costs. Health and welfare.

3. Information Technology Management (Responsible for Management Information System): IT management is the discipline whereby all the information technology resources of a firm are managed in accordance with its needs and priorities. These resources may include tangible investments like computer hardware, software facilities as well as the staff who are hired to maintain them. Managing this responsibility within an organization entails many of the basic management functions like budgeting, staffing, change management and organizing and controlling, along with other aspects that are unique to technology, like software design, network planning, technical support, etc.

As computers grow smaller and more sophisticated, IT managers are increasingly expected to function as middle managers, security consultants, and recruiters to help organizations fulfill their goals and objectives. The problems information technology managers' encounter are as follows:

1. Cloud computing

2. Cyber security/Risk management.

3. Remote management

4. Talent Retention

5. Network \& Service management

6. Time/Data management

4. Marketing management: Marketing management is the process of overseeing and planning new product development, advertising, promotions and sales. It is the process of planning and executing the conception, pricing and promoting the distribution of goods and services and ideas to create exchanges with target groups that satisfy customer and organizational objectives. All marketing managers face a unified problem. The spectrum of marketing is an ever-widening field, and they are only one person. As the world of marketing continues to expand, even the most knowledgeable marketing manager has a tough task ahead with keeping up on recent development in the promotion and marketing areas: The majority of marketing managers problems boil down to the following points:

1. Inexperience and under-staffing.

2. Difficulty in interpreting marketing data

3 Lack of departmental communication network

4. New marketing trends.

5. Closing the loop with your sales team 


\section{Operation management and production management}

5. Operation management: Operation management refers to the administration of business practices to create the highest level of efficiency possible within an organization. It is concerned with converting materials and labour into goods and services as efficiently as possible to maximize the profit of an organization. Operation management team attempts to balance cost with revenue to achieve the highest net operating profit possible. There are multiple challenges that operations managers face on a daily basis which are:
a. Globalization
b. Sustainability
c. Ethical Conduct
d. System Design
e. Effective communication

6. Production Management: This refers to the application of management principles to the production function in a factory. In order words, production management involves the application of planning, organizing, directing and controlling the production process. Production management comprises of decision making, resulting in the production of the wanted goods/things under limited cost and according to the time specified; to take such decision many problems are faced which include:

1. Selection of the product

2. Design of the equipment and processes

3. Selection of the product

4. Production design of items processed.

5. Job design

6. Site of the industry and business

7. Facility layout

8. Inventory control system

9. Productions control system

10. Maintenance and reliability of the system

11. Quality control

12. Labour control

13. Cost control and improvement 


\section{Strategic management and business policy}

7. Strategic management: Strategic management is the formulation and implementation of the major goals and initiatives taken by a company's top management on behalf of the stakeholders or owners, based on the consideration of resources and an assessment of the internal and external environments in which the organization competes. The main problems that need to be addressed are:
a. Lack of clarity and strategic objectives
b. Lack of good and focus leadership/Sponsorship for individual
c. Weak accountability for outcomes
d. Lack of coordination across the organization.
e. Weak intervention logic from outputs to outcomes
f. Weak alignment between the Budget and strategic management functions
h. Lack of double loop' learning

8. Business policy: This is the study of the roles and responsibilities of top-level management, the significant issues affecting organizational success and the decisions affecting organization in the long-run. These policies, if not properly handled, can lead to long-terms problems which include:
a. Uncertainty
b. Globalization
c. Innovation
d. Government policies and regulations
e. Technology
f. Diversity
g. Complexity
h. Information overload
i. Supply chains
j. Strategic thinking \& problem solving

\section{Some Conceptual Foundation}

Management practitioners and organizational managers as well as educators of management at whatever level both in public or private sectors have to hold certain clear and mature working understanding of management in man's environment as used or presented in this work. In the paper, management according to Henri Fayol means "to manage is to forecast and to plan, to 
organize, to command, to co-ordinate and to control. Again, Fredmund Malik defines it as the transformation of resources into utility." Finally, management in man's environment is a collaboration or a web of values invariably resulting in the occurrence of neatly arranged and understandable natural predispositions. In other words, an environment is simply a set of conditions which naturally tend to produce predictable outcome or occurrence which is readily rationalizable and organizable (Bayo \& Kayii, 2020; Osahogulu, 2003).

Summary: In this work an attempt is made at presenting to employers, employees, educators in tertiary institutions, professional management practitioners, business managers, decision/policy makers, and administrators some challenges managers are faced with on a daily basis. These challenges are highlighted to facilitate employers and employees, management practitioners on the task ahead as they work within the organizations and predominantly as they try to relate it to the everyday environment of living, learning and work, which is very familiar to members of organizations, society and to themselves.

Conclusion: Management in all of its branches can be clearly understood and readily related or applied to the natural, domestic, industrial, commercial and general societal environments familiar to employers, employees and practitioners alike. The challenges or problems have been highlighted as a working understanding offered to simplify the employers, employees and practitioners' efforts at relating every operational-level of management practices to life in the environments commonly familiar to employers, employees and practitioners.

\section{REFERENCE}

Barnett, R., Ziegler, M., Byleen, K., \& Stocker, C. (2000). Applied mathematics for business, economics, life sciences and social sciences. Prentice - Hall.

Bayo, P.L \& Kayii, N.E (2020). Knowledge-Based entrepreneurship: An agent for economic development. International Journal of Advanced Academic Research (Social and Management Sciences), 6(8), 32-42

Blythe T. et al (1998). The teaching for understanding guide. New York.

Fung, L (2015). Financial management, London school of economics and political science. LSE

Geet S. D et al (2009) Human Resource Management First Edition, De

Green R. D. (2001) Science students' perception of the constructivist features exhibited by teachers in large and small classes. Journal of Nigeria affairs, 6, (1) 59 -73.

Kotler, P (1997) Marketing management analysis, planning implementation and control prentice Hall international, Inc.

Osahogule D. J, (2003). Curriculum and instruction in printing mathematics, Port Harcourt.

Ottih L.O (2006). General management strategy, implementation and control (text and cases). Pearl publishers

Tamunomiebi M .D \& Zeb-Obipi I,(2013). Managing human resources basic principles, published by Richmond's printing press. Port Harcourt.

Vipin G, et al (2014) Business Policy and Strategic Management concept and applications. Phi learning private limited 